\title{
THE EFFECT OF CULTIVATION CONDITIONS ON GROWTH AND THERAPEUTIC ACTIVITY OF PLEUROTUS ERYNGII
}

\author{
Krupodorova T. A., Barshteyn V. Yu.
}

\section{INTRODUCTION}

Since ancient time mushrooms play an important role in traditional medicine. The attention of researchers in recent decades focuses on the comprehensive study of different genus of Macromycetes: Agaricus, Ganoderma, Pleurotus, Trametes, Lentinus and others, and their biologically active secondary metabolites. Of considerable interest is one of the important species of edible mushrooms Pleurotus eryngii (DC.) Quél., often referred to as the King Trumpet Mushroom, French Horn Mushroom, King Oyster Mushroom, King Brown Mushroom and Xingbaogu (China). Studies have shown that extracts from $P$. eryngii fruit bodies possesses numerous medicinal properties as anticancer, antiviral, antioxidant, antimicrobial, antiallergic, antiinflammatory, immunomodulating, hypolipidemic, estrogen-like activity. Various biologically active compounds have been isolated from Pleurotus eryngii: polysaccharides ( $\beta$-1,3-glucans), lovastatin, protease (pleureryn), eryngin, ribonuclease, eryngeolysin, ergothioneine, $17 \beta$-estradiol, protein $x b 68 \mathrm{AB}$, acidic-glycosphingolipids ${ }^{1,2}$. The major problem to its availability and using is limited harvests of this fungus in wildlife and their seasonality. These factors contributed to the introduction of this fungus into culture and the search for simple methods of cultivation ${ }^{3}$. Despite the numerous articles about $P$. eryngii growth on argo-industrial wastes on solid state cultivation ${ }^{4,5,6,7,8,9,10}$ a limited number of works has been

${ }^{1}$ Zhiming F., Liu Y., Zhang Q. A Potent Pharmacological Mushroom: Pleurotus eryngii. Fungal Genomics and Biology. 2016. № 6. P. 139. DOI: 10.4172/21658056.1000139 .

${ }^{2}$ Staji M., Vukojevi J. and Duleti-Lauševi S. Biology of Pleurotus eryngii and role inbiotechnological processes: a review. Critical Reviews in Biotechnology. 2009. № 29 (1). P. 55-66. DOI: 10.1080/07388550802688821.

Gregori A., Švagelj M., Pohleven J. Cultivation Techniques and Medicinal Properties of Pleurotus spp. Food Technology and Biotechnology. 2007. № 45 (3). P. 238-249.

${ }^{4}$ Gregori A., SSvagelj M., Pohleven J. Cultivation Techniques and Medicinal Properties of Pleurotus spp. Food Technology and Biotechnology. 2007. № 45 (3). P. 238-249.

5 Barshteyn V., Krupodorova T. Utilization of agro-industrial waste by higher mushrooms: modern view and trends. The Journal of Microbiology, Biotechnology and Food Sciences. 2016. № 5 (6). P. 563-577. DOI: 10.15414/jmbfs.2016.5.6.563-577.

6 Haasan F.R.H., Medany G.M., Hussein A.S.D.Cultivation of the King Oyster Mushroom (Pleurotus eryngii) in Egypt. Australian Journal of Basic and Applied Sciences. 2010. № 4 (1). № 99-105. 
carried out on investigation of some factors on mycelium growth in pure culture. It was established a relationship between various geographical location and optimum temperature and vegetative mycelium growth ${ }^{11,12}$. Also effect of culture media, alternate substrates and $\mathrm{pH}$ on mycelial growth of some Pleurotus eryngii strains has been studied ${ }^{13,14}$. Few works has been carried out on investigation of mycelium growth in submerged cultivation. It was found that 10-oxo-trans-8-decenoic acid can improve the mycelial growth of King Oyster Mushrooms both on agarplates and in liquid culture $^{15}$. Czapek's medium and static conditions were preferred for mycelium biomass production of Pleurotus eryngii ${ }^{16}$. It is obvious that the influence of cultivation conditions on mycelium biomass production and the therapeutic properties of mushroom preparations is very important ${ }^{17}$. So, the main factors that affected on $P$. eryngii mycelium growth and its therapeutic effect, such as cultural media, temperature, carbon and nitrogen sources, $\mathrm{pH}$, have been studied fragmentary. Thus, the question of optimizing the

${ }^{7}$ Moonmoon M., Uddin Md.N., Ahmed S., Shelly N.J., Khan Md.A. Cultivation of different strains of king oyster mushroom (Pleurotus ostreatus) on sawdust and rice straw in Bangladesh. Saudi Journal of Biological Sciences. 2010. № 17. P. 341-345.

${ }^{8}$ Choi U.K., Lee O.H, Kim Y.C. Effect of calcinated oyster shell powder on growth, yield, spawn run, and primordial formation of king oyster mushroom (Pleurotus eryngii). Molecules. 2011. № 10. 16 (3). P. 2313-2322. DOI: 10.3390/molecules16032313.

9 Xie C., Yan L.,Gong W., Zhu Z., Tan S., Chen D., Zhenxiu H., Peng Y. Effects of Different Substrates on Lignocellulosic Enzyme Expression, Enzyme Activity, Substrate Utilization and Biological Efficiency of Pleurotus Eryngii. Cellular Physiology and Biochemistry. 2016. № 39. P. 1479-1494.

${ }_{10}$ Atila F. Determining the Effects of Container Types on Yield and Fruitbody Features of Pleurotus eryngii Strains. International Journal of Crop Science and Technology. 2017. № 3 (1). P. 7-14.

${ }^{11}$ Alavi A., Goltape E.M., Kashy A., Arzani K., Asadi E. Investigation on Cultivation of Wild King Oyster Mushroom (Pleurotus eryngii DC: Fr. Quel) of Charmahal va Bakhtiary Province (Iran). Proceedings of The Fourth International Iran \& Russia Conference. P. 692-696.

${ }^{12}$ Soylu M.K., Boztok K., Esiyok D. Mycelial growth performance of the Pleurotus eryngii species complex strains on different temperatures. ISHS Acta Horticulturae 1123: XXIX International Horticultural Congress on Horticulture: Sustaining Lives, Livelihoods and Landscapes (IHC2014): International Symposium on High Value Vegetables, Root and Tuber Crops, and Edible Fungi Production, Supply and Demands. DOI: 10.17660/ActaHortic.2016.1123.29.

${ }_{13}$ Zăgrean V., Sbîrciog G., Buzatu M.-A., Mândru I. Effect of Nutritive Media and pH on Mycelial Growth of some Pleurotus eryngii Strains in vitro. Bulletin UASVM Horticulture. 2016. № 73 (2). P. 276-278.

${ }_{14}$ Nguyen T.M. and Ranamukhaarachchi S.L. Effect of different culture media, grain sources and alternate substrates on the mycelial growth of Pleurotus eryngii and Pleurotus ostreatus.Pakistan Journal of Biological Sciences. 2020. № 23. P. 223-230.

${ }^{15}$ Mau J.-L., Ma J.-T. Effect of 10-oxo-trans-8-decenoic acid on Mycelial growth of Pleurotus eryngii. Fungal Science. 2002. № 17 (1, 2). P. 1-9.

${ }_{16}$ Janpoor J., Pourianfar H.R., Shahtahmasebi S. Study on effect of culture medium and growth conditions on Liquid Spawn king oyster mushroom (Pleurotus eryngii). The International Journal of Farming and Allied Sciences. 2017. № 6 (6). P. 154-156.

17 Krupodorova T.A., Barshteyn V.Yu., Kizitska T.O., Pokas E.V. Effect of cultivation conditions on mycelial growth and antibacterial activity of Lentinula edodes and Fomitopsis betulina. Czech Mycoljgy. 2019. № 71 (2). P. 167-186. 
conditions of this mushroom species growth and synthesis of therapeutically active metabolites is relevant.

The aim of the current work was to investigate the effect of cultivation conditions on mycelial growth and therapeutic activity of Pleurotus eryngii.

\section{Materials and methods}

Source of basidiomycetes. Pleurotus eryngii (DC.) Quel. 2015 was kindly supplied by the Culture Collection of Mushrooms (IBK) of the M.G. Kholodny Institute of Botany of the National Academy of Sciences of Ukraine ${ }^{18}$. Stock cultures were maintained on beer-wort-agar slants at $4^{\circ} \mathrm{C}$.

Cultivation of mycelia on soil media agar. Several media were chosen to determination growth rate: Czapek Dox Agar (CZA, Sigma Aldrich), Malt Extract Agar (MEA, Difco), Potato Dextrose Agar (PDA, Difco), GlucosePeptone-Yeast Agar (GPYA) composed of $(\mathrm{g} / \mathrm{L}): 25.0$ glucose, 3.0 yeast extract, 2.0 peptone, $1.0 \mathrm{~K}_{2} \mathrm{HPO}_{4}, 1.0 \mathrm{KH}_{2} \mathrm{PO}_{4}, 0.25 \mathrm{MgSO}_{4} \cdot 7 \mathrm{H}_{2} \mathrm{O}$, and 20.0 agar. Prepared media were autoclaved at $121^{\circ} \mathrm{C}$ for $20 \mathrm{~min}$. The media were dispenses into the $9 \mathrm{~cm}$ sterile Petri dishes. The plate dishes were inoculated with mycelial agar discs (diameter $-5 \mathrm{~mm}$ ) of mushroom cut from the Petri dishes with GPYA using a sterile borer at the mycelial active growth stage. Cultivation on solid media was carried out at temperature $26 \pm 2^{\circ} \mathrm{C}$ in the dark. The vegetative growth of the mycelium of the mushroom on different media was assessed by measuring the diameter of mycelium in the Petri dish every 2 days until mushroom covered the whole plate.

Effect of incubation period on biomass production. Two liquid media were used for growth investigation in dynamics: GPY and natural media with $60 \mathrm{~g}$ amaranth flour per $11 \mathrm{H}_{2} \mathrm{O}$. The basis of natural cultivation medium was the waste after $\mathrm{CO}_{2}$-extraction of flour prepared from the Amaranthus hybridus L. grains (hereinafter referred to as amaranth flour). A. hybridus species was a variety "Ultra" (Mykolaiv Oblast, Ukraine, 2011). $\mathrm{CO}_{2}$-extraction conditions: pressure $-7.2 \mathrm{MPa}$; temperature $-24^{\circ} \mathrm{C}$; duration of extraction -2 hours.

Fully colonized Petri dish with GPYA was sterile homogenized and used for $10 \%(\mathrm{v} / \mathrm{v})$ inoculation of $250 \mathrm{ml}$ Flasks with $50 \mathrm{ml}$ respectively liquid medium sterilized by autoclaving for $20 \mathrm{~min}$ at $121^{\circ} \mathrm{C}$ and then were submerged cultivated at $26 \pm 2^{\circ} \mathrm{C}$ in a rotary shaker $(120 \mathrm{rpm})$.

Separation and biomass determination. Mycelium was separated from the medium by filtration through Whatman's filter paper № 4, washed with distilled water, dried to a constant weight at $105^{\circ} \mathrm{C}$. Fungi biomass was estimated by absolutely dry weight (a.d.w.).

18 Bisko N.A, Lomberg M.L., Mytropolska N.Y., Mykchaylova O.B. The IBK mushroom culture collection. National Academy of Sciences of the Ukraine. Kyiv : Alterpres. 120 p. 
Exopolysaccharides determination. The culture liquid after submerged cultivation was treated with $96 \%$ ethanol at a volume ratio of 1:1 to obtain exopolysaccharides (EPS) and left overnight at $4^{\circ} \mathrm{C}$. The precipitate (polysaccharide fraction) was harvested by centrifugation at $8000 \mathrm{~g}$ for $15 \mathrm{~min}$, and the precipitate of crude EPS was dried to a constant weight at $60^{\circ} \mathrm{C}^{19}$. Exopolysaccharides were absent in GPY medium. However, the content of exopolysaccharides was determined in amaranth flour in traces amount.

Effect of temperature and initial $\mathrm{pH}$ on biomass production. The GPY medium was employed to determine optimum temperature for mycelia growth (from 20 up to $30^{\circ} \mathrm{C}$ ), and $\mathrm{pH}$ values of the growth medium from 4.5 up to 6.5 . The $\mathrm{pH}$ was adjusted using $1 \mathrm{M} \mathrm{HCl}$ and $1 \mathrm{M} \mathrm{NaOH}$. Flasks $(150 \mathrm{ml})$ with $50 \mathrm{ml}$ liquid medium sterilized by autoclaving for $20 \mathrm{~min}$ at $121^{\circ} \mathrm{C}$ and then were inoculated with three mycelial plugs of $8 \mathrm{~mm}$ diameter cut from the Petri dishes with GPYA using a sterile borer at the mycelial active growth stage. Mushroom was grown as static cultures (without agitation and in the dark) in flasks for 7 days at $26 \pm 2^{\circ} \mathrm{C}$.

Effect of carbon and nitrogen sources on biomass production. Glucoseasparagine medium (g/l): 10.0 glucose, 0.4 asparagine, $1.0 \quad \mathrm{KH}_{2} \mathrm{PO}_{4}$, $0.5 \mathrm{MgSO}_{4} \cdot 7 \mathrm{H}_{2} \mathrm{O}, 11 \mathrm{H}_{2} \mathrm{O}$ has been used to determine the optimum carbon and nitrogen sources for mycelia growth. In this medium glucose was replaced by monosaccharides (arabinose, fructose, galactose, xylose), disaccharides (maltose, sucrose), polysaccharide (soluble starch) and mannitol in terms of $12 \mathrm{~g}$ of C/1 (where pure carbon per liter calculated by percentage of carbon element in the molecule). Different concentrations of arabinose $(10,15,25,30,35 \mathrm{~g})$ were dissolved in $1000 \mathrm{ml}$ inglucose-asparagine medium at $\mathrm{pH}$ of 5.5.Similarly, asparagine was replaced by different nitrogen sources (ammonium sulphate, peptone, sodium nitrate, yeast extract, urea) in terms of $0.21 \mathrm{~g}$ of N/1 (wherepure nitrogen per litre calculated by percentage of nitrogen element in the molecule). Different concentrations of asparagine 0.4, 0.8, 1.2, 1.6, $2.0 \mathrm{~g}$ were dissolved in to $1000 \mathrm{ml}$ in glucose-asparagineat $\mathrm{pH}$ of 5.5 . Flasks $(150 \mathrm{ml})$ with $50 \mathrm{ml}$ respectively liquid medium sterilized by autoclaving for $20 \mathrm{~min}$ at $121^{\circ} \mathrm{C}$ and then were inoculated with three mycelial plugs of $8 \mathrm{~mm}$ diameter cut from the Petri dishes with GPYA using a sterile borer at the mycelial active growth stage. Mushroom was grown as static cultures (without agitation and in the dark) in flasks for 7 days at $26 \pm 2^{\circ} \mathrm{C}$.

Antibacterial activity. The bacterial cultures, Bacillus subtilis UCM B-901 (ATCC 6633), Escherichia coli UCM B-906 (ATCC 25922), and Staphylococcus aureus UCM B 4001 (ATCC 65388) were kindly supplied by Ukrainian Collection of Microorganisms (UCM, Institute of microbiology and virology NAS of Ukraine). Tested microorganisms were cultured on

${ }^{19}$ Бабицкая В.Г. Базидиальные грибы - субстанция для получения функциональных препаратов. Материаль международной конференции «Современное состояние и перспективы развития микробиологии и биотехнологии». Минск, 2004. C. $230-232$. 
Mueller-Hinton agar (MHA) $\left(37^{\circ} \mathrm{C}, 24 \mathrm{~h}\right)$. Each microorganism was suspended in sterile saline and diluted to $10^{6}$ Colony Forming Units (CFU) per ml.

Antibacterial activity was determined by the agar disc diffusion method $^{20}$. Sterile paper discs $(8 \mathrm{~mm}$ diameter) with mycelium suspension (grounded into native homogenized mycelium by using mortar and pestle) or ten times evaporated cultural liquid (using the sand bath) were placed into the Petri dishes with MHA previously inoculated with the bacterial suspensions. The inoculated Petri dishes were incubated overnight at $37^{\circ} \mathrm{C}$. Antibacterial activity was evaluated by measuring the zone of inhibition against the tested organisms (in $\mathrm{mm}$, using the ruler graduated to $0.5 \mathrm{~mm}$ ). Antibacterial activity was determined to be present where the zone of inhibition was larger than $8 \mathrm{~mm}$ (exceeding diameter of the inserted paper disc). Distilled water was used as a negative control.

Antiviral activity. Cell lines and viruses, cytotoxicity assay and antiviral assay consistent with those set out in our article ${ }^{21}$.

Antifungal activity. The Ascomycetes cultures: Issatchenkia orientalis Kudryavtsev 301, Candida albicans (C.P. Robin) Berkhout 17/138 and clinical strains of $C$. albicans 311, 315, 319 were from the Culture Collection of Microorganisms of the Institute of Epidemiology and Infectious Diseases of the National Academy of Medical Sciences of Ukraine. Aspergillus niger, Mucor sp. and Penicillium sp. were from the Collection of strains of microorganisms and plant lines of the Institute of Food Biotechnology and Genomics of the National Academy of Sciences of Ukraine. Stock cultures were maintained on potato dextrose agar slants at $4^{\circ} \mathrm{C}$.

All Ascomycetes were transferred from stored cultures to Petri dishes with PDA and cultured at $26 \pm 1^{\circ} \mathrm{C}$ to obtain mycelial colonies. In the phase of active growth of cultures, mycelial discs of $P$. eryngi with a diameter of $8 \mathrm{~mm}$ has been cut.

We investigated direct interaction of studied fungi by their ability to suppress the mycelial growth in dual culture on PDA using a rating scale for the 3 main types of reactions $(\mathrm{A}, \mathrm{B}, \mathrm{C})$ and 4 sub-types $\left(\mathrm{C}_{\mathrm{A} 1}, \mathrm{C}_{\mathrm{B} 1}, \mathrm{C}_{\mathrm{A} 2}\right.$, and $\mathrm{C}_{\mathrm{B} 2}$ ) by method described by Badalyan, Innocenti \& Garibyan ${ }^{22}$.

To determinate the inhibition growth, three discs were transferred to $250 \mathrm{ml}$ flasks containing $50 \mathrm{ml}$ of GPY nutrient medium and incubated at $26 \pm 1^{\circ} \mathrm{C}$ at static conditions. After 14 days of cultivation, surface mycelium was sterile removed, and the culture liquid was mixed with previously prepared and cooled to $40{ }^{\circ} \mathrm{C}$ GPYA nutrient medium, in a ratio of $1: 1$. The

${ }^{20}$ Методы экспериментальной микологии / Билай В.И. (ред). Киев : Наукова думка, 1982. $550 \mathrm{c}$.

${ }^{21}$ Krupodorova T., Rybalko S., Barshteyn V. Antiviral activity of Basidiomycete mycelia against influenza type A (serotype H1N1) and herpes simplex virus type 2 in cell culture. Virologica Sinica. 2014. № 29 (5). P. 284-290. DOI: 10.1007/s12250-014-3486-y.

${ }_{22}$ Badalyan S.M., Innocenti G., Garibyan N.G. Antagonistic activity of xylotrophic mushrooms against pathogenic fungi of cereals in dual culture. Phytopathologia Mediterranea. 2002. № 41 (3). P. 220-225. 
resulting mixture (a culture liquid with mycelium residues that did not grow on the surface but in the middle of the medium) was poured into Petri dishes with a diameter of $45 \mathrm{~mm}$. After the medium was solidified, one micromycetes disk was introduced into the center of the Petri dish. Antifungal activity was determined at 7 days of cultivation by the percentage of growth inhibition according to the Vincent formula ${ }^{23}$. Taking into account the peculiarity of Penicillium sp. the strain to formation numerous of small colonies, the degree of inhibition of its growth was assessed qualitatively: "-" no inhibition, "+" weak, "++" strong inhibition of growth (growth of macromycetes on top of pathogen culture).

Statistical analysis. All experiments were carried out in triplicate. The data were analyzed by Excel statistical functions using the Microsoft Office XP software, Statistical Package for Social Sciences, Program 11.5 Version (SPSS, Inc., 2002). Values are presented as means, with a \pm standard error of the mean (SEM). Differences at $\mathrm{P} \leq 0.05$ were considered to be significant.

\section{Results and discussion}

The maintenance of a pure culture mycelium and investigations of its physico-chemical parameters needed for obtailing a high production and are the first critical stage towards the success of spawn production and mushroom cultivation. It is necessary to take into account that for different isolates and strains of the same fungi species optimal growth conditions can varied. The growth of vegetative mycelium and colony morphology are an important criterion of culture characteristics for biotechnological application. The influence of nutrient media on the growth rate (fig. 1) and on the morphology of colonies (table 1, fig. 2) of P. eryngii was determined. The average mycelial growth rate of studied media ranged between $7.7 \pm 0.3$ and $12.6 \pm 0.6 \mathrm{~mm} /$ day with the highest growth rate obtained on CZA (fig. 1). This medium without agar also was more suitable for biomass production of $P$. eryngii in other study ${ }^{24}$. However, the tender, spider-like colony morphology due to very thinner mycelium was inconvenient for further work. No statistically significant differences were found for mycelium growth rate on the GPYA and PDA culture media. However, researchers have reported about different media for optimum P. eryngii mycelial growth: glucose peptone ${ }^{25}$, yeast malt extract ${ }^{26,27,28,29}$, mushroom complete ${ }^{30,31}$,

\footnotetext{
${ }^{23}$ Vincent J.M. Distortion of fungal hyphae in the presence of certain inhibitors. Nature. 1947. № 159. 850 p. DOI: 10.1038/159850b0.

${ }^{24}$ Janpoor J., Pourianfar H.R., Shahtahmasebi S. Study on effect of culture medium and growth conditions on Liquid Spawn king oyster mushroom (Pleurotus eryngii). The International Journal of Farming and Allied Sciences. 2017. № 6 (6). P. 154-156.

${ }^{25}$ Alam N., Shim M.J., Lee M.W., Shin P.G., Yoo Y.B. and Le T.S. Vegetative Growth and Phylogenetic Relationship of Commercially Cultivated Strains of Pleurotus eryngiibased on ITS sequence and RAPD. Mycobiology. 2009. № 37 (4). P. 258-266.

${ }_{26}$ Alavi A., Goltape E.M., Kashy A., Arzani K., Asadi E. Investigation on Cultivation of Wild King Oyster Mushroom (Pleurotus eryngii DC: Fr. Quel) of Charmahal va
} 
potato-dextrose ${ }^{32,33}$, lilly ${ }^{34}$. Obtained our results are significant better compared to other similarly experiments of $P$. eryngii growth on MEA (4.96-5.79 $\mathrm{mm} /$ day), wheat extract agar $(1.54-2.75 \mathrm{~mm} /$ day $)$, PDA $(1.68-$ $3.04 \mathrm{~mm} /$ day $)^{35}$, and on yeast malt extract agar $(0.7-4.2 \mathrm{~mm} / \text { day })^{36}$.

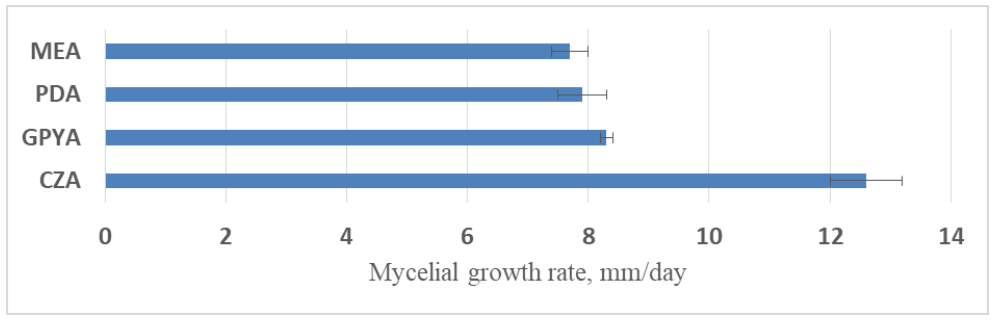

Fig.1. Effect of culture media on $\boldsymbol{P}$. eryngii mycelia growth. CZA - Czapek Dox Agar, MEA - Malt Extract Agar, PDA - Potato Dextrose Agar, GPYA - Glucose-Peptone-Yeast Agar

Bakhtiary Province (Iran). Proceedings of The Fourth International Iran \& Russia Conference. P. 692-696.

${ }^{27}$ Zăgrean V., Sbîrciog G., Buzatu M.-A., Mândru I. Effect of Nutritive Media and pH on Mycelial Growth of some Pleurotus eryngii Strains in vitro. Bulletin UASVM Horticulture. 2016. № 73 (2). P. 276-278.

${ }^{28}$ Alam N., Shim M.J., Lee M.W., Shin P.G., Yoo Y.B. and Le T.S. Vegetative Growth and Phylogenetic Relationship of Commercially Cultivated Strains of Pleurotus eryngiibased on ITS sequence and RAPD. Mycobiology. 2009. № 37 (4). P. 258-266.

${ }^{29}$ Sardar H., Ali M.A., Ayyub C.M., Ahmad R. Effects of different culture media, temperature and $\mathrm{pH}$ levels on the growth of wild and exotic Pleurotus species. Pakistan Journal of Phytopathology. 2015. № 27 (02). P. 139-145.

${ }^{30}$ Alam N., Shim M.J., Lee M.W., Shin P.G., Yoo Y.B. and Le T.S. Vegetative Growth and Phylogenetic Relationship of Commercially Cultivated Strains of Pleurotus eryngii based on ITS sequence and RAPD. Mycobiology. 2009. № 37 (4). P. 258-266.

${ }^{3}$ Ryu J.-S., Kim M.-K., Kwon J.-H., Cho S.-H., Kim N.-K., Rho C.-W., Lee C.-H., Ro H.-S., Lee H.-S. The Growth Characteristics of Pleurotus eryngii. The Korean Journal of Mycology. 2007. № 35 (1). P. 47-53.

${ }^{32}$ Nguyen T.M. and Ranamukhaarachchi S.L. Effect of different culture media, grain sources and alternate substrates on the mycelial growth of Pleurotus eryngii and Pleurotus ostreatus. Pakistan Journal of Biological Sciences. 2020. № 23. P. 223-230.

${ }^{33}$ Sardar H., Ali M.A., Ayyub C.M., Ahmad R. Effects of different culture media, temperature and $\mathrm{pH}$ levels on the growth of wild and exotic Pleurotus species. Pakistan Journal of Phytopathology. 2015. № 27 (02). P. 139-145.

${ }^{34}$ Kim H.-K., Cheong J.-C., Chang H.-Y., Kim G.P., Cha D.-Y., Moon B.-J. The Artificial Cultivation of Pleurotus eryngii (I) Investigation of Mycelial Growth Conditions. The Korean Journal of Mycology. 1997. № 25 (4). P. 305-310.

${ }^{35}$ Zăgrean V., Sbîrciog G., Buzatu M.-A., Mândru I. Effect of Nutritive Media and pH on Mycelial Growth of some Pleurotus eryngii Strains in vitro. Bulletin UASVM Horticulture. 2016. № 73 (2). P. 276-278.

${ }^{36}$ Alavi A., Goltape E.M., Kashy A., Arzani K., Asadi E. Investigation on Cultivation of Wild King Oyster Mushroom (Pleurotus eryngii DC: Fr. Quel) of Charmahal va Bakhtiary Province (Iran). Proceedings of The Fourth International Iran \& Russia Conference. P. 692-696. 
Table 1

Morphology of $P$. eryngii colonies on different culture media

\begin{tabular}{|c|c|c|c|c|c|}
\hline \multirow{2}{*}{$\begin{array}{c}\text { Culture } \\
\text { media }\end{array}$} & Color & $\begin{array}{c}\text { Form / } \\
\text { Edge }\end{array}$ & $\begin{array}{c}\text { Mycelial } \\
\text { growth }\end{array}$ & Texture & Surface \\
\cline { 2 - 6 } PDA & white & $\begin{array}{c}\text { circular / } \\
\text { fimbriate }\end{array}$ & $\begin{array}{c}\text { prostrate }- \\
\text { aerial }\end{array}$ & $\begin{array}{c}\text { cottony: rather long, } \\
\text { single mycelial hyphae } \\
\text { spreading in all } \\
\text { directions }\end{array}$ & flat \\
\hline GPYA & $\begin{array}{c}\text { white and } \\
\text { light yellow } \\
\text { in the } \\
\text { centrum of } \\
\text { colony }\end{array}$ & $\begin{array}{c}\text { circular / } \\
\text { fimbriate }\end{array}$ & $\begin{array}{c}\text { prostrate - } \\
\text { aerial } \\
\text { CZA }\end{array}$ & $\begin{array}{c}\text { coriaceous in the } \\
\text { centrum and velvety: a } \\
\text { dense mat of erect, } \\
\text { straight hyphae, usually } \\
\text { short }\end{array}$ & flat \\
\hline MEA & light yellow & $\begin{array}{c}\text { circular / } \\
\text { smooth }\end{array}$ & prostrate & $\begin{array}{c}\text { spider-like with cotton in } \\
\text { the centrum of colony }\end{array}$ & flat \\
\hline fimbriate & $\begin{array}{c}\text { prostrate }- \\
\text { aerial }\end{array}$ & $\begin{array}{c}\text { woolly: fairly long } \\
\text { interwoven hyphae or } \\
\text { groups of hyphae, } \\
\text { somewhat matted, } \\
\text { resembling woolen cloth }\end{array}$ & flat \\
\hline
\end{tabular}

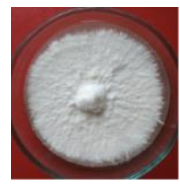

a

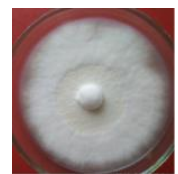

b

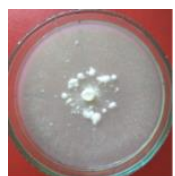

$\mathrm{c}$

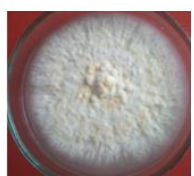

d

Fig. 2. Illustration of $P$. eryngii colonies on different culture media:

$$
\text { a - PDA, b - GPYA, c - CZA, d - MEA }
$$

Of particular interest is the study of the patterns of mushroom growth in submerged cultivation. The production of mushroom biomass on standard and natural media are quite actual and promising trends in modern biotechnology. The influence of the nutrient medium on biomass and exopolysaccharides production of $P$. eryngii in submerged cultivation has been studied. The obtained data of the dynamics of biomass accumulation on two used liquid medium were subordinate to the general regularities of microorganism's development in submerged cultivation conditions (fig. 3). The results of the study showed that maximum amount of biomass $15.3 \pm 0.2 \mathrm{~g} / \mathrm{l}$ and $14.5 \pm 0.8 \mathrm{~g} / \mathrm{l}$ was obtained on the $8^{\text {th }}$ day of cultivation on GPY medium and $10^{\text {th }}$ day of cultivation on amaranth flour medium, respectively. But crude exopolysaccharides production was better established on natural media. The obtained biomass amount are slightly better than the results of the positive effect of 10-oxo-trans-8-decenoic acid on the growth of $P$. eryngii $(10.2-12.6 \mathrm{~g} / \mathrm{l})$ on 12 days of cultivation ${ }^{14}$ and 
significantly exceed of the results (from $1.5 \mathrm{mg} / \mathrm{ml}$ to $2.7 \mathrm{mg} / \mathrm{ml}$ ) obtained on different media by submerged cultivation with and without shaking ${ }^{37}$.

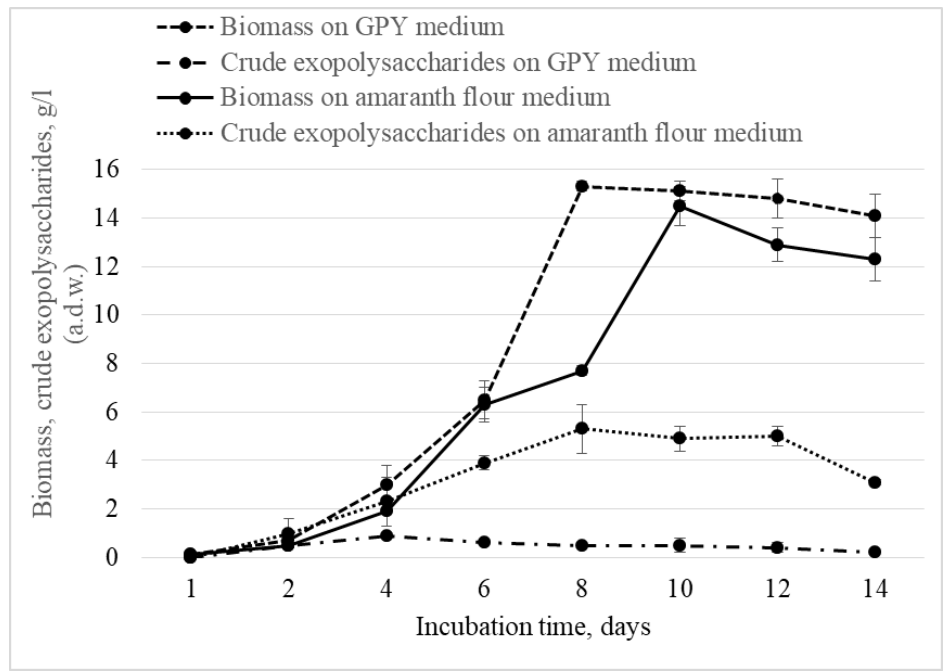

\section{Fig. 3. Dynamics of $P$. eryngii biomass and crude exopolysaccharides production in shake flasks using different media}

It's well known that temperature has significant effect on metabolic reactions of fungi. The optimum temperature for $P$. eryngii growing was $20 \pm 1^{\circ} \mathrm{C}$ (fig. 4). Our results are in line with those that shown optimum temperature $20^{\circ} \mathrm{C}$ for vegetative growth rateof $P$. eryngii ${ }^{38}$. In other studies, the most appropriate temperature for mycelial growth were $25^{\circ} \mathrm{C}^{39,40}, 25-30^{\circ} \mathrm{C}^{41}, 30^{\circ} \mathrm{C}^{42}$. It has been reported that different $P$. eryngii

${ }^{37}$ Mau J.-L., Ma J.-T. Effect of 10-oxo-trans-8-decenoic acid on Mycelial growth of Pleurotus eryngii. Fungal Science. 2002. № 17 (1, 2). P. 1-9.

38 Janpoor J., Pourianfar H.R., Shahtahmasebi S. Study on effect of culture medium and growth conditions on Liquid Spawn king oyster mushroom (Pleurotus eryngii). The International Journal of Farming and Allied Sciences. 2017. № 6 (6). P. 154-156.

${ }^{9}$ Alavi A., Goltape E.M., Kashy A., Arzani K., Asadi E. Investigation on Cultivation of Wild King Oyster Mushroom (Pleurotus eryngii DC: Fr. Quel) of Charmahal va Bakhtiary Province (Iran). Proceedings of The Fourth International Iran \& Russia Conference. P. 692-696.

${ }^{40}$ Soylu M.K., Boztok K., Esiyok D.Mycelial growth performance of the Pleurotus eryngii species complex strains on different temperatures. ISHS Acta Horticulturae 1123: XXIX International Horticultural Congress on Horticulture: Sustaining Lives, Livelihoods and Landscapes (IHC2014): International Symposium on High Value Vegetables, Root and Tuber Crops, and Edible Fungi Production, Supply and Demands. DOI: 10.17660/ActaHortic.2016.1123.29. 
strains growth at broad range of temperature $\left({ }^{\circ} \mathrm{C}\right): 10,15,20,25,30$, where the optimum temperature were found to be $20-30^{\circ} \mathrm{C}$ depending on the strain of the fungus and cultivation medium ${ }^{43}$.

Mycelium structure and function (in particular cell morphology, cell membrane function, the solubility of salts, the uptake of necessary nutrients) of fungi significant depends of the $\mathrm{pH}$ of initial medium. It was established that mycelium of $P$. eryngii could grow over a studied range of $\mathrm{pH}$ values with quite smaller differences. The best growth was obtained at $5.0-5.5 \mathrm{pH}$ values since we did not observe a statistically significant difference in mycelial growth at these $\mathrm{pH}$ (fig. 5). This observation is in line with Alam et al. $^{44}$ which established that $P$. eryngii growth within $\mathrm{pH}$ ranging from 5 9 without any significant variation. Some researches ${ }^{45,46,47,48}$ found that for P. eryngii strains maximum mycelial growth was determined at $\mathrm{pH} 6.0$.

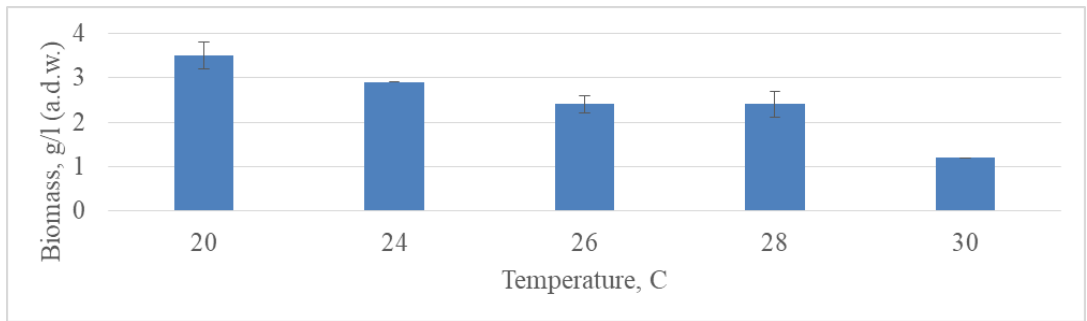

Fig. 4. Effect of temperature on $P$. eryngii biomass production

${ }^{41}$ Sardar H., Ali M.A., Ayyub C.M., Ahmad R. Effects of different culture media, temperature and $\mathrm{pH}$ levels on the growth of wild and exotic Pleurotus species. Pakistan Journal of Phytopathology. 2015. № 27 (02). P. 139-145.

${ }^{42}$ Kim H.-K., Cheong J.-C., Chang H.-Y., Kim G.P., Cha D.-Y., Moon B.-J. The Artificial Cultivation of Pleurotus eryngii (I) Investigation of Mycelial Growth Conditions. The Korean Journal of Mycology. 1997. № 25(4). P. 305-310.

${ }^{43}$ Miyauchi, S., Kon, K., Yamachi, T. \& Shimomura, M. Cultural characteristics of mycelial growth of Pleurotus eryngii. 1998. Nipon. Kingakakai, Kaiho. № 39 (3). P. 83-87.

${ }_{44}$ Ryu J.-S., Kim M.-K., Kwon J.-H., Cho S.-H., Kim N.-K., Rho C.-W., Lee C.-H., Ro H.-S., Lee H.-S. The Growth Characteristics of Pleurotus eryngii. The Korean Journal of Mycology. 2007. № 35(1). P. 47-53.

${ }^{45}$ Alam N., Shim M.J., Lee M.W., Shin P.G., Yoo Y.B. and Le T.S. Vegetative Growth and Phylogenetic Relationship of Commercially Cultivated Strains of Pleurotus eryngiibased on ITS sequence and RAPD. Mycobiology. 2009. № 37 (4). P. 258-266.

${ }^{46}$ Zăgrean V., Sbîrciog G., Buzatu M.-A., Mândru I. Effect of Nutritive Media and pH on Mycelial Growth of some Pleurotus eryngii Strains in vitro. Bulletin UASVM Horticulture. 2016. № 73 (2). P. 276-278.

47 Alam N., Shim M.J., Lee M.W., Shin P.G., Yoo Y.B. and Le T.S. Vegetative Growth and Phylogenetic Relationship of Commercially Cultivated Strains of Pleurotus eryngiibased on ITS sequence and RAPD. Mycobiology. 2009. № 37 (4). P. 258-266.

${ }_{48}$ Sardar H., Ali M.A., Ayyub C.M., Ahmad R. Effects of different culture media, temperature and $\mathrm{pH}$ levels on the growth of wild and exotic Pleurotus species. Pakistan Journal of Phytopathology. 2015. № 27 (02). P. 139-145. 


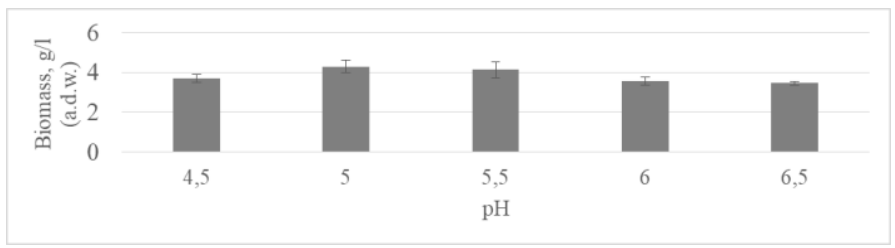

Fig. 5. Effect of initial pH on $P$. eryngii biomass production

The studying of the trophic needs is important for understanding the physiology of mushroom growth. Carbon and nitrogen sources are of paramount importance since they play an important role in growth and development processes. Carbon is needed for synthesis of living cell substances and is involved in oxidation processes in which it is the only one source of energy. Our work indicates that $P$. eryngii can utilized a broad range of carbon sources, such as monosaccharides, disaccharides, and polysaccharides (fig. 6). But arabinose in concetration $20 \mathrm{~g} / \mathrm{l}$ was the most suitable carbon source for $P$. eryngii biomass production (fig. 7). This finding is in line with the ecology of this fungi, which is a weak parasite since arabinose is one of the widespread reserve substance of Apiaceae plants (Eryngium spp. and Ferula spp.) on the roots naturally grow $P$. eryngii. In the previous reports $P$. eryngii needed for the growth various sources of carbon: dextrin, followed by fructose, mannose and maltose ${ }^{49}$, glucose (3-4\%) and dextrin $(5 \%)^{50}$, glucose, starch, and sucrose ${ }^{51}$.

Nitrogen-containing compounds play a significant role in metabolism of fungi. Among the nitrogen sources used in this study, asparagine was found to be the best nitrogen source for biomass production of P.eryngii (fig. 8). It was established that asparagine in concentration 0.8-1.6 g/l supported biomass synthesis at the same level (fig. 9). In other study ${ }^{52}$, casamino acid $(0.12 \%)$ was the most appropriated nitrogen source for $P$. eryngii mycelial growth. However good growth was obtained in medium with serine,

${ }^{49}$ Alam N., Shim M.J., Lee M.W., Shin P.G., Yoo Y.B. and Le T.S. Vegetative Growth and Phylogenetic Relationship of Commercially Cultivated Strains of Pleurotus eryngii based on ITS sequence and RAPD. Mycobiology. 2009. № 37 (4). P. 258-266.

${ }^{50}$ Kim H.-K., Cheong J.-C., Chang H.-Y., Kim G.P., Cha D.-Y., Moon B.-J. The Artificial Cultivation of Pleurotus eryngii (I) Investigation of Mycelial Growth Conditions. The Korean Journal of Mycology. 1997. № 25 (4). P. 305-310.

51 Altaf S.A., Umar D.M., Muhammad M.S. Production of Xylanase Enzyme by Pleurotus eryngii and Flamulina velutipes Grown on Different Carbon Sources under Submerged Fermentation. World Applied Sciences Journal 8 (Special Issue of Biotechnology \& Genetic Engineering). 2010. P. 47-49.

${ }_{52}$ Kim H.-K., Cheong J.-C., Chang H.-Y., Kim G.P., Cha D.-Y., Moon B.-J. The Artificial Cultivation of Pleurotus eryngii (I) -Investigation of Mycelial Growth Conditions. The Korean Journal of Mycology. 1997. № 25(4). P. 305-310. 
glutamic acid, asparagine, alanine, and urea. Ammonium acetate was found to be the best mycelial growth of $P$. eryngii, followed by arginine and urea $^{53}$.

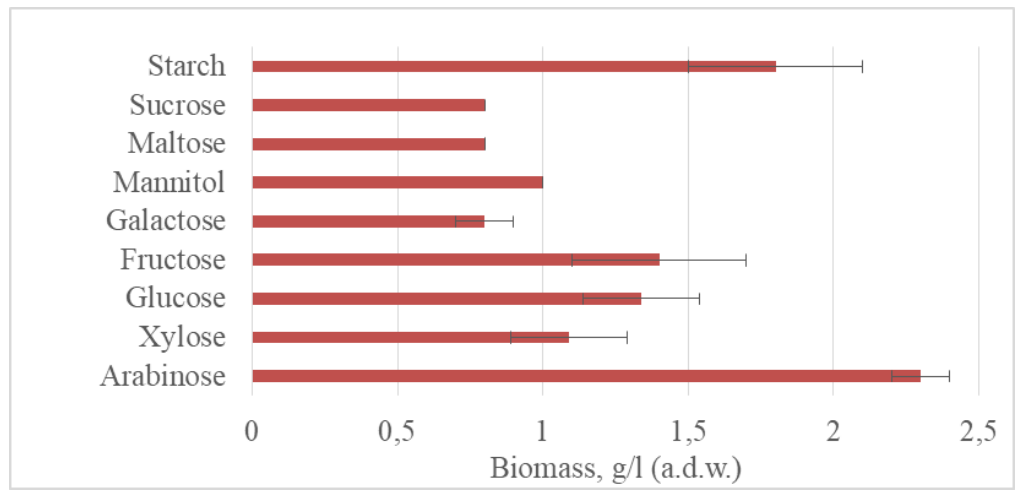

Fig. 6. Effect of carbon sources on $P$. eryngii biomass production

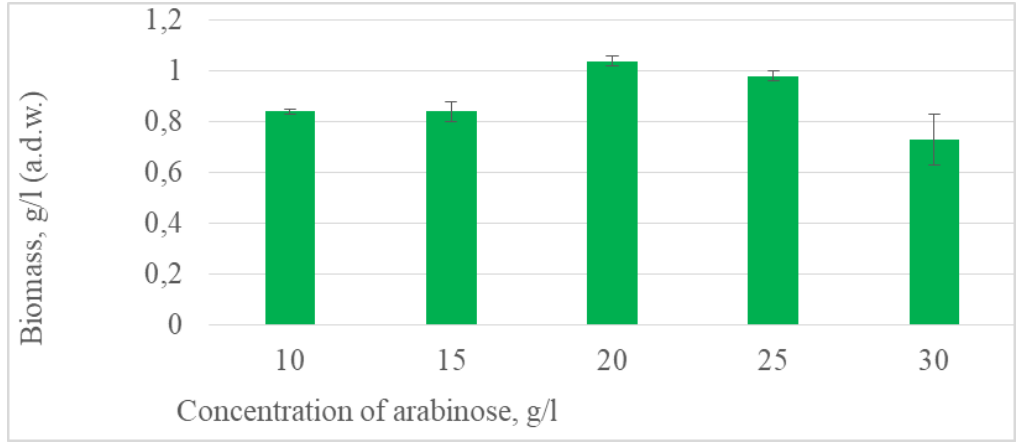

Fig. 7. Effect of arabinose concentration on $P$. eryngii biomass production

Thus, taking into account the results of the conducted research and analysis of literature data, basic needs (temperature, $\mathrm{pH}$, carbon and nitrogen sources) of fungi growth is quite specifically for every strains or isolates. The understanding of the physiological needs of fungi and observing their optimal cultivation conditions will contribute to obtaining their high productivity.

${ }^{53}$ Alam N., Shim M.J., Lee M.W., Shin P.G., Yoo Y.B. and Le T.S. Vegetative Growth and Phylogenetic Relationship of Commercially Cultivated Strains of Pleurotus eryngii based on ITS sequence and RAPD. Mycobiology. 2009. № 37 (4). P. 258-266. 


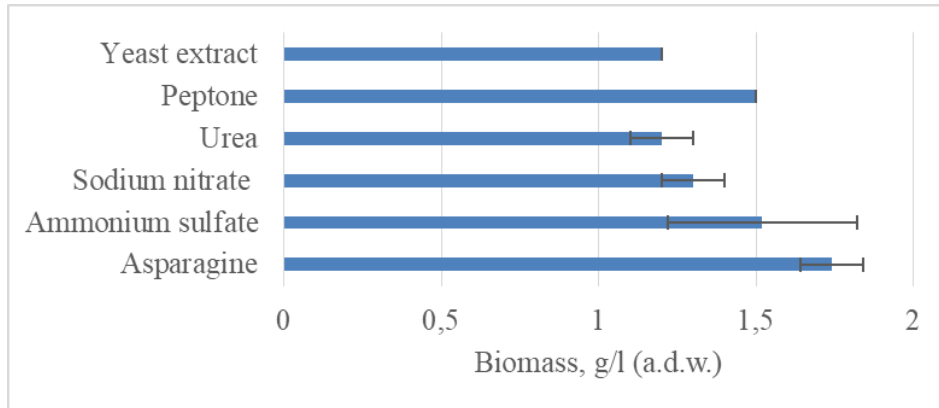

Fig. 8. Effect of nitrogen sources on P. eryngii biomass production

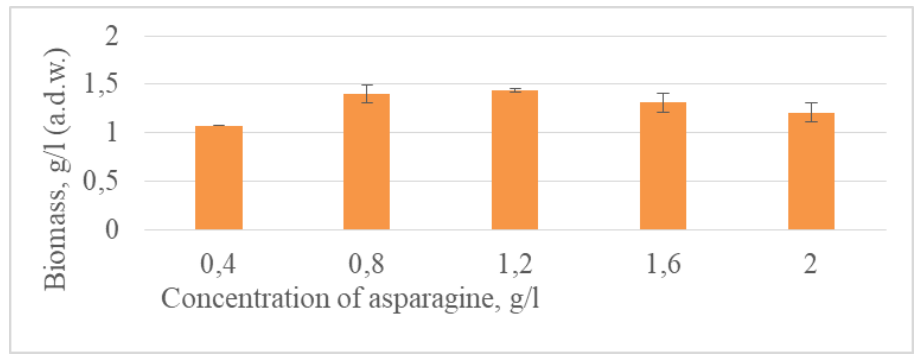

Fig. 9. Effect of asparagine concentration on $P$. eryngii biomass production

The growing of basidiomycete's biomass in controlled conditions is the important direction in the development of new drugs. Therefore, investigations aimed at studying the therapeutic properties of fungi are of particular importance. And it opens up new prospects for the use of biomass of fungi and their metabolites obtained in culture. It was established that P. eryngii possessed different pharmacological activities: anticancer, antioxidant, antimicrobial, anti-allergic, antihypercholesterolic, antiosteoporotic, immunomodulating ${ }^{54,55}$. Research on antiviral, antibacterial, and antagonistic activity is gaining significant attention.

The prevention and treatment of viral diseases remains an urgent problem in modern medicine. Virus infection is one of the challenging

${ }^{54}$ Zhiming F., Liu Y., Zhang Q. A Potent Pharmacological Mushroom: Pleurotus eryngii. Fungal Genomics and Biology. 2016. № 6. P. 139. DOI: 10.4172/21658056.1000139.

${ }^{55}$ Staji M., Vukojevi J. and Duleti-Lauševi S. Biology of Pleurotus eryngii and role inbiotechnological processes: a review. Critical Reviews in Biotechnology. 2009. № 29 (1). P. 55-66. DOI: 10.1080/07388550802688821. 
global issues with regular widespread epidemics or pandemics resulting in high mortality worldwide ${ }^{56}$. We investigated in vitro the antiviral activity of $P$. eryngii mycelia obtained on culture medium with amaranth flour against influenza virus A/FM/1/47 (H1N1) and against herpes virus type 2 (HSV). In general, it should be noted slight antiviral activity of $P$. eryngii mycelia. Extracts from $P$. eryngii mycelia inhibited the reproduction of influenza virus strain $\mathrm{A} / \mathrm{FM} / 1 / 47(\mathrm{H} 1 \mathrm{~N} 1)$ in MDCK cells reducing the infectious titre by $2.0 \mathrm{lg}$ ID $50^{57}$. However, mycelial extract of this fungus was inactivity against HSV-2. Previously, it was established, that the protease from $P$. eryngii designated pleureryn was active against HIV-1 growth with an IC50 of $2.2 \mu \mathrm{M}$ by inhibiting HIV-1 reverse transcriptase. A protease was isolated from fresh fruiting bodies of $P$. eryngii, caused $(23.1 \pm 0.6) \%$ and $(91.4 \pm 3.2) \%$ inhibition of HIV-1 reverse transcriptase at 3 and $30 \mathrm{mM}$, respectively ${ }^{58}$.

At the same time, the expediency of finding new highly effective antimicrobial drugs and raw materials for medical purposes is undeniable. The feasibility of such studies is also due to the prevalence of resistance to antibacterial and antifungal drugs. It's known that fungi need antibacterial and antifungal compounds to survive in their natural environment ${ }^{59}$. We studied mycelum and culture liquid of $P$. eryngii cultivated on two liquid media: glucose-peptone-yeast agar culture medium and natural liquid medium with amaranth flour ${ }^{60}$. It should be noted that the use of the natural medium for the cultivation of the fungus allowed us to establish the presence of antibacterial activity. P. eryngii mycelium cultivated on amaranth flour medium showed moderate antibacterial activity only against Bacillus subtilis (zone of inhibition $-10.0 \pm 0.0 \mathrm{~mm}$ ). Previously, the influence of cultivation substrates (various agrowastes) on the antimicrobial activity of fruiting bodies $P$. eryngii var. ferulae was also demonstrated ${ }^{61}$. Studied samples of $P$. eryngii (mycelium and culture liquid) were inactive against Staphylococcus aureus and Escherichia coli. Similar results - moderate

${ }^{56}$ Zhiming F., Liu Y., Zhang Q. A Potent Pharmacological Mushroom: Pleurotus eryngii. Fungal Genomics and Biology. 2016. № 6. P. 139. DOI:10.4172/21658056.1000139 .

${ }^{57}$ Krupodorova T., Rybalko S., Barshteyn V. Antiviral activity of Basidiomycete mycelia against influenza type A (serotype H1N1) and herpes simplex virus type 2 in cell culture. Virologica Sinica. 2014. № 29 (5). P. 284-290. DOI: 10.1007/s12250-014-3486-y.

${ }_{58}$ Wang H, Ng T.B. Pleureryn, a novel protease from fresh fruiting bodies of the edible mushroom Pleurotus eryngii. Biochemical and Biophysical Research Communications. 2001. № 289. P. 750-755.

59 Yamaç M., Bilgili F. Antimicrobial Activities of Fruit Bodies and/or Mycelial Cultures of Some Mushroom Isolates. Pharmaceutical Biology. 2006. № 44 (9). P. 660-667. DOI: 10.1080/13880200601006897.

${ }^{60}$ Zhiming F., Liu Y., Zhang Q. A Potent Pharmacological Mushroom: Pleurotus eryngii. Fungal Genomics and Biology. 2016. № 6. P. 139. DOI: 10.4172/21658056.1000139

${ }_{61}$ Akyuz M., Kirbag S. Antimicrobial activity of Pleurotus eryngii var.ferulae grown on various agro-wastes. EurAsian Journal of BioSciences. 2009. № 3. P. 58-63. 
antibacterial activity against $B$. subtilis and $E$. coli were demonstrated by other authors in submerged culture ${ }^{62}$. Some studies reported that $P$. eryngii extracts performed inhibitory property against a group of bacterial reference strains of medical relevance ${ }^{63}$.

Continuing a series of studies of the therapeutic activity of $P$. eryngii, we investigated the antifungal activity of its mycelium by direct interactions with micromycetes and of cultural liquid with mycelium fragments by evaluation the growth inhibition of micromycetes in percentage in dual culrure. It is known that antibacterial and antifungal activities often correlate with each other. But in our case, the antifungal activity of $P$. eryngii was more pronounced than the antibacterial. The direct interactions between all tested fungi shown different results. The best result (replacement overgrowth) was obtained in the case of $P$. eryngii and Saccharomycetaceae fungi cultivation: complete, replacement after initial deadlock with mycelial contact (subtype $\mathrm{C}_{\mathrm{A} 2}$ ) was observed with $I$. orientalis and $C$. albicans 17/138; partial replacement (subtype $\mathrm{C}_{\mathrm{A} 1}$ ) - with clinical isolates $C$. albicans 311 and 319; replacement overgrowth without initial deadlock (type C) with $C$. albicans 315 . It was established mutual inhibition when neither organism was able to overgrow the other at mycelial contact of $P$. eryngii and $A$. niger. In addition, subtype $\mathrm{C}_{\mathrm{A} 1}$ was characteristic during cultivation P. eryngii and Penicillium sp. However, a partial growth of Mucor sp. on colony $P$. eryngii was observed. The calculation of the antagonistic index (AI), calculated using the well-known formula ${ }^{64}$, indicates significant antifungal activity of $P$. eryngii. AI for $P$. eryngii was 23.5 (13-14 result from 30 studied macromycetes).

We obtained a similar antifungal activity of mycelium fragments and culture liquid of $P$. eryngii obtained by cultivation in a liquid potato-dextrose medium. High antifungal activity of $P$. eryngii was found in our study also against Saccharomycetaceae fungi, which had $100 \%$ growth inhibition of I. orientalis and all $C$. albicans strains. The inhibition of $A$. niger growth was established at $57.6 \%$. P. eryngii was less effective against Penicillium sp. A weak effect of $P$. eryngii was observed on the ability of Penicillium sp. to the formation of numerous small colonies. Wang and $\mathrm{Ng}^{65}$ isolated from

\footnotetext{
${ }^{62}$ Краснопольская Л.М., Тренин А.С., Бычкова О.П., Цвигун Е.А., Джавахян Б.Р. Погруженная культура Pleurotus eryngii: антибиотические свойства и способность к образованию ингибиторов биосинтеза стеролов. Universum: Химия и биология. 2015. № 11 (18). URL: http://7universum.com/ru/nature/archive/item/2703.

${ }^{6}$ Zhiming F., Liu Y., Zhang Q. A Potent Pharmacological Mushroom: Pleurotus eryngii. Fungal Genomics and Biology. 2016. № 6. P. 139. DOI:10.4172/21658056.1000139.

${ }^{64}$ Badalyan S.M., Innocenti G., Garibyan N.G. Antagonistic activity of xylotrophic mushrooms against pathogenic fungi of cereals in dual culture. Phytopathologia Mediterranea. 2002. № 41 (3). P. 220-225.

${ }^{65}$ Wang H., Ng T.B. Eryngin, a novel antifungal peptide from fruiting bodies of the edible mushroom Pleurotus eryngii isolated from fruiting bodies of the mushroom Pleurotus eryngii. Peptides. 2004 . № 25 (1). P. 1-5.
} 
fruiting bodies of $P$. eryngii an antifungal peptide designated as eryngin inhibited mycelial growth of Fusarium oxysporum and Mycosphaerella arachidicola.

Thus, the mycelium and culture liquid of $P$. eryngii obtained on different media have insignificant antiviral, antibacterial activity and possess relative strong antifungal action.

\section{CONCLUSIONS}

The understanding of the impact of nutritional requirements of mushrooms is a key component toward designing efficient biotechnology strategies. Obtaining the high yield of fungi biomass depends on many factors, first of all, on satisfaction the needs of mushrooms for nutrients, which is directly dependent on the nutrient medium. Among these factors also: medium acidity, temperature, incubation period, cultivation method. Moreover, these factors are unique for each strain of fungi. The average mycelial growth rate on Czapek Dox Agar, Malt Extract Agar, Potato Dextrose Agar, Glucose-Peptone-Yeast Agar composed media ranged between $7.7 \pm 0.3$ and $12.6 \pm 0.6 \mathrm{~mm}$ /day with the highest obtained on Czapek Dox Agar. Temperature $20^{\circ} \mathrm{C}$ and $\mathrm{pH}$ values between 5.0-5.5, presence of arabinose (concentration $-20 \mathrm{~g} / \mathrm{l}$ ) and asparagine (concentration $0.8-1.6 \mathrm{~g} / \mathrm{l}$ ) gave the best results for $P$. eryngii biomass synthesis. The biomass and exopolysacharides synthesis of $P$. eryngii varied depending on the media employed. Considering the insignificant difference of biomass formation on the studied media and the best indicators of the synthesis of exopolysaccharides on the natural medium, amaranth flour medium is more appropriated medium for these purposes.

The growing of fungi biomass in controlled conditions is an actually direction in the development of new drugs with low toxicity. P. eryngii mycelium and its culture liquid obtained on different media have some therapeutically activities: slight antiviral against influenza virus strain $\mathrm{A} / \mathrm{FM} / 1 / 47(\mathrm{H} 1 \mathrm{~N} 1)$ with the reducing of the infectious titre by $2.0 \lg$ ID50, insignificant antibacterial activity against Bacillus subtilis (zone of inhibition $-10.0 \pm 0.0 \mathrm{~mm}$ ) and strong antifungal action against Issatchenkia orientalis, Candida albicans strains including clinical isolates, good effect against $A$. niger and less effective against Penicillium sp.

In general, the biomass production of the fungus largely depends on most of the studied factors, such as temperature, duration and culture medium, sources of nitrogen and carbon. Only the acidity of the medium had a negligible effect of biomass accumulation. The influence of the medium cultivation on mycelial growth, morphology of colonies, crude exopolysaccharides production and on the manifestation of antibacterial activity was also established.

Obtained results serve as a base or provide information of nutritional requiremets for $P$. eryngii growth and of its some therapeutically potential. 
The strategies used in this study can help increasing vegetative growth and can be useful by substrates chosing for $P$. eryngii cultivation.

\section{SUMMARY}

Last time of considerable interest is one of the important edible mushrooms Pleurotus eryngii, which fruit bodies possesses numerous medicinal properties. The main factors that affected on $P$. eryngii mycelium growth and its therapeutic effect have been studied fragmentary. Thus, the optimizing the growth conditions and synthesis of therapeutically active metabolites is relevant.

The highest mycelial growth rate has been obtained in this work on Czapek Dox Agar. Temperature $20^{\circ} \mathrm{C}$ and $\mathrm{pH}$ values between 5.0-5.5, presence of arabinose and asparagine gave the best results for $P$. eryngii biomass synthesis.

P. eryngii mycelium and its culture liquid demonstrated some therapeutic activities: slight antiviral against influenza virus strain A/FM/1/47(H1N1), insignificant antibacterial activity against Bacillus subtilis and strong antifungal action against Issatchenkia orientalis, Candida albicans strains including clinical isolates, good effect against Aspergillus niger and was less effective against Penicillium sp.

\section{REFERENCES}

1. Zhiming F., Liu Y., Zhang Q. A Potent Pharmacological Mushroom: Pleurotus eryngii. Fungal Genomics and Biology. 2016. № 6. P. 139. DOI: 10.4172/2165-8056.1000139.

2. Staji M., Vukojevi J. and Duleti-Lauševi S. Biology of Pleurotus eryngii and role inbiotechnological processes: a review. Critical Reviews in Biotechnology. 2009. № 29 (1). P. 55-66. DOI: 10.1080/07388550802688821.

3. Gregori A., Švagelj M., Pohleven J. Cultivation Techniques and Medicinal Properties of Pleurotus spp. Food Technology and Biotechnology. 2007. № 45 (3). P. 238-249.

4. Barshteyn V., Krupodorova T. Utilization of agro-industrial waste by higher mushrooms: modern view and trends. The Journal of Microbiology, Biotechnology and Food Sciences. 2016. № 5 (6). P. 563-577. DOI: 10.15414/jmbfs.2016.5.6.563-577.

5. Haasan F.R.H., Medany G.M., Hussein A.S.D.Cultivation of the King Oyster Mushroom (Pleurotus eryngii) in Egypt. Australian Journal of Basic and Applied Sciences. 2010. № 4 (1). P. 99-105.

6. Moonmoon M., Uddin Md.N., Ahmed S., Shelly N.J., Khan Md.A. Cultivation of different strains of king oyster mushroom (Pleurotus ostreatus) on sawdust and rice straw in Bangladesh. Saudi Journal of Biological Sciences. 2010. № 17. P. 341-345. 
7. Choi U.K., Lee O.H, Kim Y.C.Effect of calcinated oyster shell powder on growth, yield, spawn run, and primordial formation of king oyster mushroom (Pleurotus eryngii). Molecules. 2011. № 10. 16 (3). P. 2313-2322. DOI: 10.3390/molecules16032313.

8. Xie C., Yan L.,Gong W., Zhu Z., Tan S., Chen D., Zhenxiu H., Peng Y. Effects of Different Substrates on Lignocellulosic Enzyme Expression, Enzyme Activity, Substrate Utilization and Biological Efficiency of Pleurotus Eryngii. Cellular Physiology and Biochemistry. 2016. № 39. P. 1479-1494.

9. Atila F. Determining the Effects of Container Types on Yield and Fruitbody Features of Pleurotus eryngii Strains. International Journal of Crop Science and Technology. 2017. № 3 (1). P. 7-14.

10. Alavi A., Goltape E.M., Kashy A., Arzani K., Asadi E. Investigation on Cultivation of Wild King Oyster Mushroom (Pleurotus eryngii DC: Fr. Quel) of Charmahal va Bakhtiary Province (Iran). Proceedings of The Fourth International Iran \& Russia Conference. P. 692-696.

11. Soylu M.K., Boztok K., Esiyok D. Mycelial growth performance of the Pleurotus eryngii species complex strains on different temperatures. ISHS Acta Horticulturae 1123: XXIX International Horticultural Congress on Horticulture: Sustaining Lives, Livelihoods and Landscapes (IHC2014): International Symposium on High Value Vegetables, Root and Tuber Crops, and Edible Fungi Production, Supply and Demands. DOI: 10.17660/ActaHortic.2016.1123.29.

12. Zăgrean V., Sbîrciog G., Buzatu M.-A., Mândru I. Effect of Nutritive Media and $\mathrm{pH}$ on Mycelial Growth of some Pleurotus eryngii Strains in vitro. Bulletin UASVM Horticulture. 2016. № 73 (2). P. 276-278.

13. Nguyen T.M. and Ranamukhaarachchi S.L. Effect of different culture media, grain sources and alternate substrates on the mycelial growth of Pleurotus eryngii and Pleurotus ostreatus. Pakistan Journal of Biological Sciences. 2020. № 23. P. 223-230.

14. Mau J.-L., Ma J.-T. Effect of 10-oxo-trans-8-decenoic acid on Mycelial growth of Pleurotus eryngii. Fungal Science. 2002. № 17 (1, 2). P. 1-9.

15. Janpoor J., Pourianfar H.R., Shahtahmasebi S. Study on effect of culture medium and growth conditions on Liquid Spawn king oyster mushroom (Pleurotus eryngii). The International Journal of Farming and Allied Sciences. 2017. № 6 (6). P. 154-156.

16. Krupodorova T.A., Barshteyn V.Yu., Kizitska T.O., Pokas E.V. Effect of cultivation conditions on mycelial growth and antibacterial activity of Lentinula edodes and Fomitopsis betulina. Czech Mycoljgy. 2019. № 71 (2). P. 167-186.

17. Bisko N.A, Lomberg M.L., Mytropolska N.Y., Mykchaylova O.B. The IBK mushroom culture collection. National Academy of Sciences of the Ukraine. Kyiv : Alterpres. 120 p. 
18. Бабицкая В.Г. Базидиальные грибы - субстанция для получения функциональных препаратов. Материаль международной конференции «Современное состояние и перспективы развития микробиологии и биотехнологии». Минск, 2004. С. 230-232.

19. Методы экспериментальной микологии / Билай В.И. (ред). Киев : Наукова думка, 1982. 550 с.

20. Krupodorova T., Rybalko S., Barshteyn V. Antiviral activity of Basidiomycete mycelia against influenza type A (serotype H1N1) and herpes simplex virus type 2 in cell culture. Virologica Sinica. 2014. № 29 (5). P. 284-290. DOI: 10.1007/s12250-014-3486-y.

21. Badalyan S.M., Innocenti G., Garibyan N.G. Antagonistic activity of xylotrophic mushrooms against pathogenic fungi of cereals in dual culture. Phytopathologia Mediterranea. 2002. № 41 (3). P. 220-225.

22. Vincent J.M. Distortion of fungal hyphae in the presence of certain inhibitors. Nature. 1947. № 159. 850 p. DOI:10.1038/159850b0.

23. Alam N., Shim M.J., Lee M.W., Shin P.G., Yoo Y.B. and Le T.S. Vegetative Growth and Phylogenetic Relationship of Commercially Cultivated Strains of Pleurotus eryngiibased on ITS sequence and RAPD. Mycobiology. 2009. № 37 (4). P. 258-266.

24. Sardar H., Ali M.A., Ayyub C.M., Ahmad R. Effects of different culture media, temperature and $\mathrm{pH}$ levels on the growth of wild and exotic Pleurotus species. Pakistan Journal of Phytopathology. 2015. № 27 (02). P. 139-145.

25. Ryu J.-S., Kim M.-K., Kwon J.-H., Cho S.-H., Kim N.-K., Rho C.-W., Lee C.-H., Ro H.-S., Lee H.-S. The Growth Characteristics of Pleurotus eryngii. The Korean Journal of Mycology. 2007. № 35 (1). P. 47-53.

26. Kim H.-K., Cheong J.-C., Chang H.-Y., Kim G.P., Cha D.-Y., Moon B.-J. The Artificial Cultivation of Pleurotus eryngii (I) Investigation of Mycelial Growth Conditions. The Korean Journal of Mycology. 1997. № 25 (4). P. 305-310.

27. Miyauchi, S., Kon, K., Yamachi, T. \& Shimomura, M. Cultural characteristics of mycelial growth of Pleurotus eryngii. 1998. Nipon. Kingakakai, Kaiho. № 39 (3). P. 83-87.

28. Altaf S.A., Umar D.M., Muhammad M.S. Production of Xylanase Enzyme by Pleurotus eryngii and Flamulina velutipes Grown on Different Carbon Sources under Submerged Fermentation. World Applied Sciences Journal 8 (Special Issue of Biotechnology \& Genetic Engineering). 2010. P. 47-49.

29. Wang H, Ng T.B. Pleureryn, a novel protease from fresh fruiting bodies of the edible mushroom Pleurotus eryngii. Biochemical and Biophysical Research Communications. 2001. № 289. P. 750-755.

30. Yamaç M., Bilgili F. Antimicrobial Activities of Fruit Bodies and/or Mycelial Cultures of Some Mushroom Isolates. Pharmacentical Biology. 2006. № 44 (9). P. 660-667. DOI: 10.1080/13880200601006897. 
31. Krupodorova T.A., Barshteyn V.Yu., Zabeida E.F., and Pokas E.V. Antibacterial Activity of Macromycetes Mycelia and Culture Liquid. Microbiology and Biotechnology Letters. 2016. № 44 (3). P. 246-253. DOI: 10.4014/mbl.1603.03003.

32.Akyuz M., Kirbag S. Antimicrobial activity of Pleurotus eryngii var.ferulae grown on various agro-wastes. EurAsian Journal of BioSciences. 2009. № 3. Р. 58-63.

33. Краснопольская Л.М., Тренин А.С., Бычкова О.П., Цвигун Е.А., Джавахян Б.Р. Погруженная культура Pleurotus eryngii: антибиотические свойства и способность к образованию ингибиторов биосинтеза стеролов.Universum: Химия и биология. 2015. № 11 (18). URL: http://7universum.com/ru/nature/archive/item/2703.

34. Wang H., Ng T.B. Eryngin, a novel antifungal peptide from fruiting bodies of the edible mushroom Pleurotus eryngiiisolated from fruiting bodies of the mushroom Pleurotus eryngii. Peptides. 2004. № 25 (1). P. 1-5.

Information about authors:

Krupodorova T. A.,

Candidate of Biological Sciences, Senior Researcher of the Laboratory for Extraction of Vegetable Raw

Materials and Bioconversion Institute of Food Biotechnology and Genomics of the National Academy of Sciences of Ukraine 2a, Osipovskogo Str., Kyiv, 04123, Ukraine;

Barshteyn V. Yu.

Candidate of Technical Sciences, Head of the Laboratory for Extraction of Vegetable Raw Materials and Bioconversion Institute of Food Biotechnology and Genomics of the National Academy of Sciences of Ukraine 2a, Osipovskogo Str., Kyiv, 04123, Ukraine 